\title{
Proteomics analysis after traumatic brain injury in rats: the search for potential biomarkers
}

\author{
Análise proteômica após lesão cerebral traumática em ratos: a busca por biomarcadores

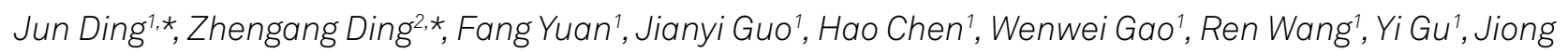 \\ Chen', Yan Guo', Hengli Tian ${ }^{1}$
}

\begin{abstract}
Many studies of protein expression after traumatic brain injury (TBI) have identified biomarkers for diagnosing or determining the prognosis of TBI. In this study, we searched for additional protein markers of TBI using a fluid perfusion impact device to model TBI in S-D rats. Two-dimensional gel electrophoresis and mass spectrometry were used to identify differentially expressed proteins. After proteomic analysis, we detected 405 and 371 protein spots within a pH range of 3-10 from sham-treated and contused brain cortex, respectively. Eighty protein spots were differentially expressed in the two groups and 20 of these proteins were identified. This study validated the established biomarkers of TBI and identified potential biomarkers that could be examined in future work.
\end{abstract}

Keywords: traumatic brain injury, biomarkers, proteomics, two-dimensional gel electrophoresis, mass spectrometry.

\section{RESUMO}

Muitos estudos de expressão proteica após lesão cerebral traumática (LCT) identificam biomarcadores para determinação diagnóstica ou prognóstica do LCT. No presente estudo, foram investigados marcadores proteicos adicionais de LCT, através de um aparelho de impacto no fluxo e perfusão em ratos S-D. Eletroforese bidimensional em gel e espectrometria de massa foram utilizadas para identificar diferentes proteínas expressas. Após a análise proteômica, detectamos marcas de proteínas 405 e 371, com pH variando entre 3-10 no córtex de ratos sham e naqueles com contusão cerebral, respectivamente. Oitenta marcas proteicas foram expressas nos dois grupos e 20 destas proteínas foram identificados. Este estudo validou o estabelecimento de biomarcadores de LCT e identificou potencial biomarcadores que poderão ser estudados em estudos futuros.

Palavras-chave: lesão traumática cerebral, biomarcadores, proteômica, eletroforese bidimensional em gel, espectrometria de massa.

Traumatic brain injury (TBI) is the leading cause of traumatic death and disability worldwide ${ }^{1}$. The main causes of TBI are motor vehicle accidents (50\%), falls (21\%), assaults and violence (12\%), sports and recreation (10\%), and other $(7 \%)^{2}$. TBI patients impose a tremendous burden on their families and society, and increase demands on the healthcare system. In order to achieve favorable outcomes, rapid diagnosis and treatment are important.

TBI triggers complex changes to the central nervous system (CNS). A better understanding of its complex pathobiology is required to further our ability to evaluate and care for brain injury patients. However, an understanding of the mechanisms and biomarkers of TBI remains elusive. Biomarkers reflecting the biological response to injury or disease have proven useful for diagnosing many disorders, including responses to injury, cancer, heart failure, infection, and genetic disorders (Table 1$)^{3}$. Many biomarkers of TBI have been identified, although they are not widely used clinically. These markers include S-100ß, neuron specific enolase (NSE), glial fibrillary acid protein (GFAP), and myelin basic protein (MBP). Although these proteins are still being assessed, they appear to lack either the sensitivity or specificity (except GFAP) to be used effectively alone ${ }^{4}$. However, combinations of these markers can provide valuable information

\footnotetext{
'Shanghai Jiaotong University affiliated Sixth People's Hospital, Department of Neurosurgery, Shanghai, 200233, China;

${ }^{2}$ Chinese Medicine Hospital of Huangdao District (Jiaonan), Department of Neurosurgery, Shandong province, 266406, China.

Correspondence: Heng-Li Tian; Shanghai Jiaotong University Sixth People's Hospital, Department of Neurosurgery; Shanghai 200233, China; E-mail:tianhlsh@126.com Conflict of interest: There is no conflict of interest to declare.

* These authors contributed equally to this work.

Support: National Nature and Science Foundation of China (grant no. 81271383, 81471245), the Shanghai Science and Technique Committee (grant no. 13411951401) and the Shanghai Municipal Health Bureau project (grant no. 20114242).

Received 15 July 2014; Received in final form 07 November 2014; Accepted 27 November 2014.
} 
Table 1. Biochemical markers of injury in various organ systems.

\begin{tabular}{lc}
\hline Organ & Markers \\
\hline Heart & $\begin{array}{c}\text { Troponin, creatine phosphokinase (CPK)-MB } \\
\text { Aspartate aminotransferase (AST), alanine } \\
\text { aminotransferase (ALT), alkaline phosphatase, } \\
\gamma \text {-glutamyl transpeptidase (GGTP) } \\
\text { Lipase, amylase } \\
\text { Pancreas }\end{array}$ \\
$\begin{array}{l}\text { Muscle } \\
\text { Kidney }\end{array}$ & CPK-MM \\
Brain & Blood urea nitrogen (BUN), creatinine (Cr) \\
\hline
\end{tabular}

and effectively diagnose and predict the outcome of $\mathrm{TBI}^{5}$. Given their potential utility for determining the diagnosis and prognosis of brain injuries, their clinical utility should be explored further.

Proteomic analysis is a powerful tool for the global evaluation of protein expression and has been applied widely in the analysis of disease ${ }^{6}$. Analyses of the TBI proteome can aid in our understanding of the association between protein changes and brain injury, and several studies have already applied proteomics to the identification of biomarkers for $\mathrm{TBI}^{7}$.

Proteomic analysis is a discovery-based method that invariably identifies many proteins that differ in abundance between control and experimental samples. TBI studies use samples such as brain tissue (often from animals), cerebrospinal fluid (CSF), and blood for proteomic analysis. These samples contain information related to the CNS. Of the proteins found in CSF samples, $76 \%$ were unique to that biofluid. By contrast, plasma and serum proteins have wide, dynamic concentration ranges and it is often difficult to discover a disease-specific biomarker within the background of blood-borne housekeeping proteins? Consequently, the ideal samples for proteomic analysis are brain tissue and CSF.

\section{METHOD}

\section{Animal model}

Forty male Sprague-Dawley rats weighing 250-300 g were randomized into sham-operated or injury groups ( $n=20$ /group). Rats were acclimated in a humidified room and maintained on a standard pellet diet at the Animal Center of Shanghai Jiao Tong University School of Medicine for 10 days before the experiment. The temperature in both the feeding and operating rooms was maintained at approximately 25 to $28^{\circ} \mathrm{C}$. A fluid perfusion impact device was used to model TBI in the rats, as described previous$l^{8}$. All of the surgical, injury, and animal care protocols described below were approved by the Scientific and Ethics Committee of Shanghai Jiaotong University affiliated Sixth People's Hospital (Permit no. SYXK20130608). The rats in the TBI group were anesthetized with pentobarbital (3.5\%, $40 \mathrm{mg} / \mathrm{kg}$ ), shaved, and then placed in a stereotaxic frame. Surgery was performed as described by Sullivan and colleagues 9 . Briefly, a 6-mm ipsilateral craniotomy tangential to the bregma and the sagittal suture was made, leaving the underlying dura mater intact. A 5-mm-wide impactor tip was adjusted so that it just touched the exposed dura mater and was secured over the right parietal cortex. The next day, the animals were anesthetized, intubated, and then placed under a fluid-percussion brain injury device. A moderate fluidpercussion pulse ( $2.0 \pm 0.2$ atmospheres) was delivered to the right parietal cortex. Sham-operated rats underwent all of the surgical manipulations, but without the fluid-percussion pulse, and were monitored under anesthesia for $30 \mathrm{~min}$ after the sham operation. All of the animals were kept in the same environment after surgery for 48 hours.

\section{Specimens}

The sham-operated and TBI animals were anesthetized $48 \mathrm{~h}$ postoperatively and sacrificed by decapitation. Immediately following decapitation, the brain was removed and the cortex samples were dissected rapidly over dry ice. All of the samples were washed with ice-cold saline before freezing to reduce brain contamination with blood proteins. Samples were then stored in liquid nitrogen for further processing. Injured cortex samples were dissected to about $2 \mathrm{~mm}$ from the injury spot; sham samples were removed from the same location. The total time from decapitation to snap freezing of the samples was about $5 \mathrm{~min}$ for all animals in both groups.

\section{Two-dimensional gel electrophoresis}

First, $100 \mathrm{mg}$ of tissue sample was ground into a powder in liquid nitrogen, homogenized in $1 \mathrm{ml}$ of lysis buffer $(7 \mathrm{M}$ urea, $2 \mathrm{M}$ thiourea, $4 \%$ CHAPS, $30 \mathrm{mM}$ Tris-HCl, protease inhibitor mixture) on ice, and sonicated ( $10 \times 10$-s pulses) on ice. The homogenate was centrifuged at $12,000 \mathrm{rpm}$ for $30 \mathrm{~min}$ at $4^{\circ} \mathrm{C}$. The protein was precipitated with cold acetone at $-20^{\circ} \mathrm{C}$ for $2 \mathrm{~h}$ and dissolved with rehydration buffer ( $8 \mathrm{M}$ urea, $2 \mathrm{M}$ thiourea, $4 \%$ CHAPS, 100 mM DTT, $2 \%$ ampholyte). Protein concentrations were determined using the Bradford method (Bio-Rad). Immobilized pH gradient (IPG) strips $(18 \mathrm{~cm}$, pH 4-7, non-linear; Bio-Rad) were rehydrated passively using $400 \mu \mathrm{l}$ of rehydration buffer for $12 \mathrm{~h}$ at $17^{\circ} \mathrm{C}$. Isoelectric focusing electrophoresis (IEF) was performed on an IEF cell (Bio-Rad). The strips were equilibrated in equilibration buffer (25 mM Tris-HCl (pH 8.8), $6 \mathrm{M}$ urea, 20\% glycerol, $2 \%$ SDS, $130 \mathrm{mM} \mathrm{DTT}$ ) for $15 \mathrm{~min}$ and then in the same buffer containing $200 \mathrm{mM}$ iodoacetamide instead of DTT for another $15 \mathrm{~min}$. The two-dimensional gel electrophoresis (2-DE) separation was performed on $12 \%$ sodium dodecyl sulfatepolyacrylamide gel electrophoresis (SDS-PAGE) gels. The gels were stained using Coomassie Brilliant Blue R-350 (Merck), according to the supplier's protocol. 
In-gel tryptic digestion and protein identification by mass spectrometry

In-gel tryptic digestion and protein identification by mass spectrometry (MS) were performed as described elsewhere ${ }^{6}$. Briefly, protein spots of interest were excised and destained. Ingel digestion was performed with $0.01 \mu \mathrm{g} / \mu \mathrm{l}$ trypsin (Promega) for $20 \mathrm{~h}$ at $37^{\circ} \mathrm{C}$. The tryptic peptides were extracted from the gel and dried by centrifugal lyophilization. The peptide mixtures were redissolved in $0.5 \%$ trifluoroacetic acid (TFA) and analyzed on an AB4700 Proteomics Analyzer (Bruker Daltonics Inc.). Peptide mass maps were acquired in positive reflection mode, averaging 1,500 laser shots per matrix-assisted laser desorption/ionization time-of-flight (MALDI-TOF) spectrum and 3,000 shots per TOF/TOF spectrum.

\section{Data analysis}

After gel staining, the protein spots were detected, quantified, and matched using PD-Quest 2D analysis software (BioRad). Each sample was run in triplicate. Protein identificated by mass spectrometry (MS), and the MS/MS data were assigned using a MASCOT search against the NCBInr database. Redundant proteins that appeared in the database under different names and accession numbers were eliminated. If more than one protein was identified in one spot, the single protein with the highest protein score was selected from the multiprotein family. Statistical calculations were performed by SPSS statistical software (version 16.0; SPSS, Inc.). Comparison between two groups was performed by Wilcoxon two-sample test. Statistical significance was defined as $\mathrm{p}<0.05$.

\section{RESULTS}

\section{Differentially expressed proteins in the sham-operated and TBI groups}

Contused brain cortex from TBI rats and brain cortex from sham-operated rats were analyzed in triplicate using 2-DE. Coomassie staining of the gels detected 405 and 371 protein spots within a $\mathrm{pH}$ range from 3-10 from the

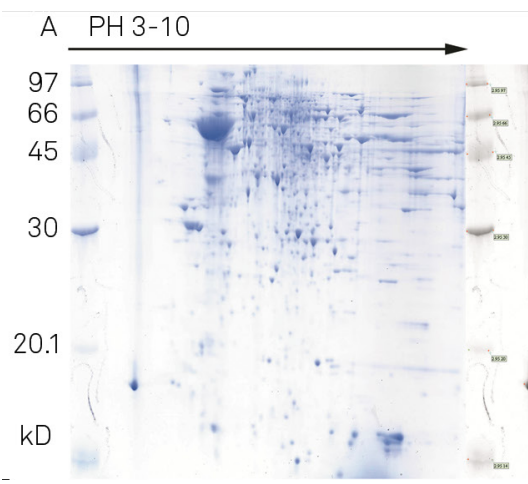

sham-operated and contused cortex, respectively (Figure 1). Statistically, 80 protein spots were differentially expressed in the sham-operated and TBI rats brain cortices $(\mathrm{p}<0.05)$.

\section{Mass spectrum identification of differentially expressed proteins}

The differentially expressed protein spots were subjected to MS/MS analysis. Twenty proteins were identified from the 80 spots (Table 2). Of these, some were expressed more strongly in the sham-operated group (spot numbers: 49, 70, 109, 158, 231, 248, 254, 289 and 369), and others were expressed more strongly in the TBI group (spot numbers: 11, 31, 55, 97, 171, 300, 307, 358, 365, 387 and 388). MS/MS analysis showed these spots had different MASCOT scores and sequence coverage. The predicted molecular masses/pI values for the 20 spots are listed below, and fit the position of the corresponding spot on the 2-DE gel well (Table 2, Figure 2).

Of the 20 identified proteins, NSE, GFAP, S100B, $\alpha$ II-spectrin, and MAP2 have been studied as biomarkers of TBI (proteomic data not shown in Table 2). Tumor biomarkers such as 14-3-3 protein have not been studied in TBI. Proteins associated with cell apoptosis were also identified, such as GAPDH and RhoB. The other identified proteins have not been examined in relation to TBI and little is known regarding their function, such as nebulin-related anchoring protein and zinc finger protein 180.

\section{DISCUSSION}

This study used proteomic analyses to identify 20 proteins that were differentially expressed in the sham-operated and TBI groups of rats. These included proteins previously identified as biomarkers of TBI, such as NSE, GFAP, S100B, aII-spectrin, and MAP2. Others had not been identified in TBI patients or animals, including the tumor indicators M2-PK and 14-3-3 protein. The functions of some of the proteins that were identified after TBI have not been established.

NSE (spot no. 11) is a biomarker of TBI and has been studied in infants, children, and adults, and in mild and severe
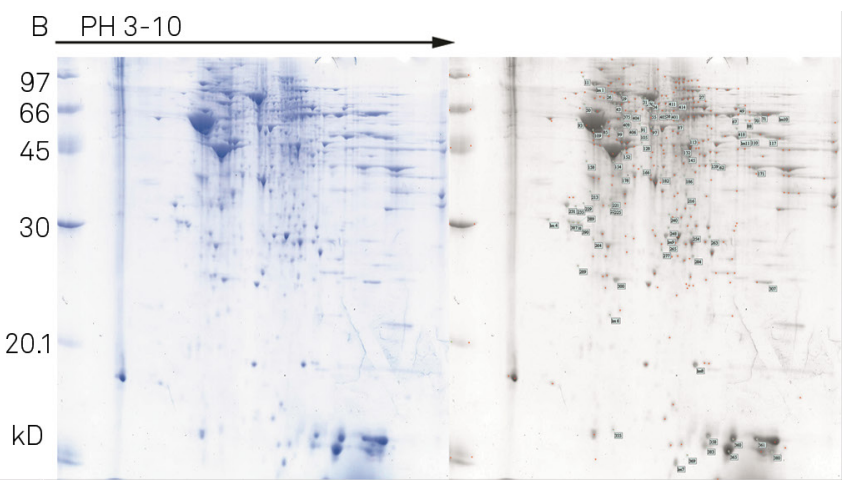

Figure 1. Proteomic analysis of sham-operated and traumatic brain injury (TBI) brain cortex using 2-DE. 


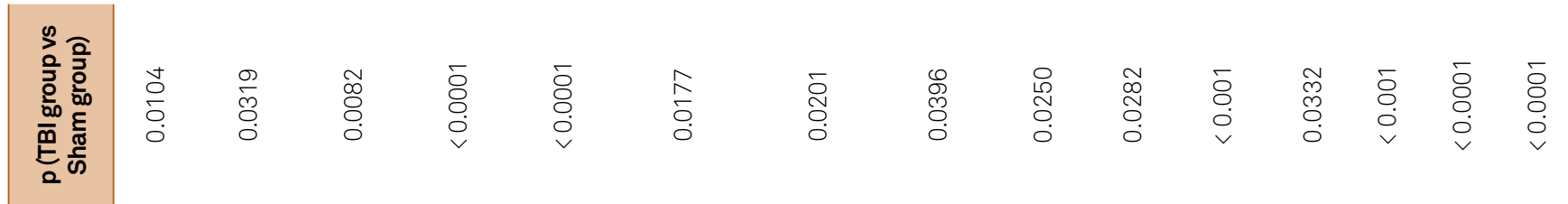

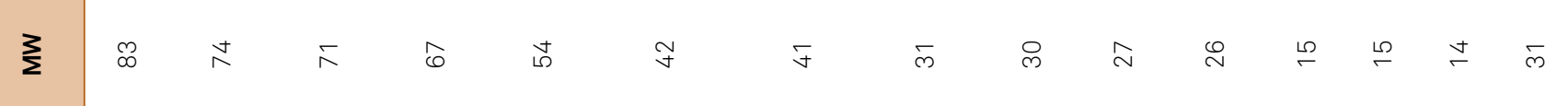

$$
\begin{aligned}
& \text { In }
\end{aligned}
$$

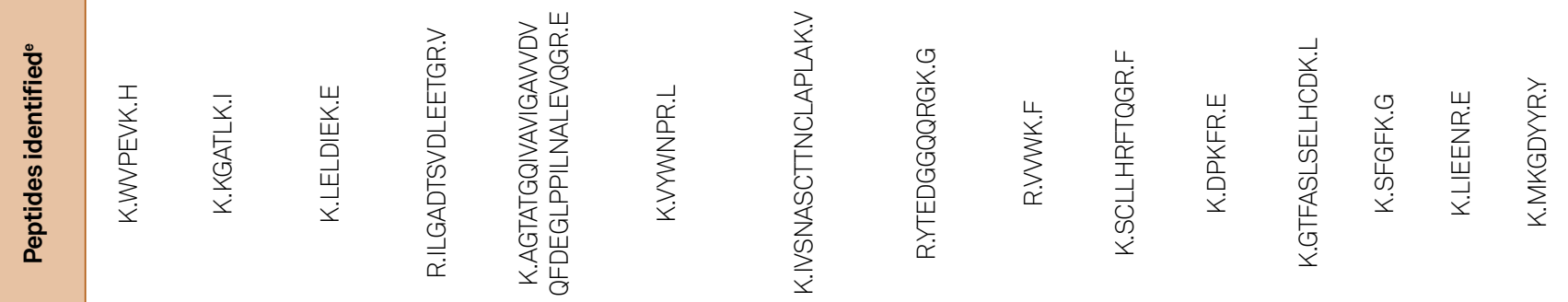

$$
\begin{aligned}
& \text { II }
\end{aligned}
$$

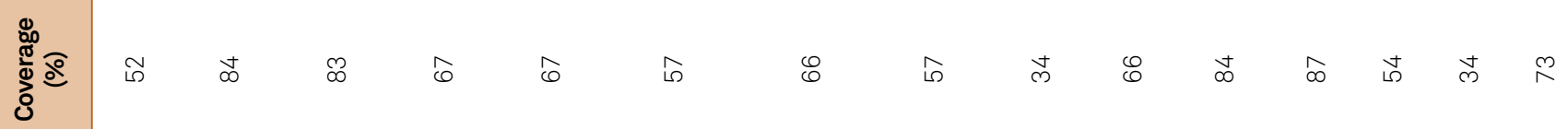

$$
\begin{aligned}
& \text { W }
\end{aligned}
$$

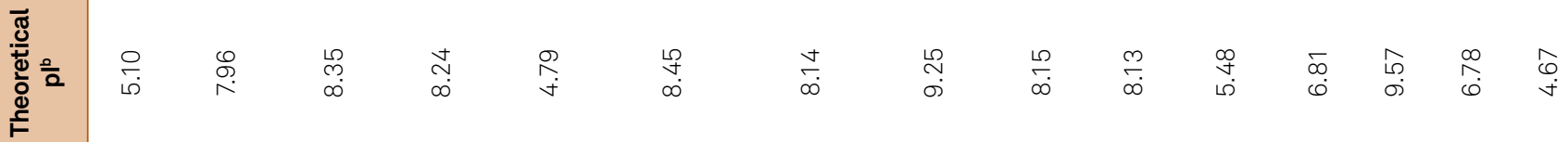

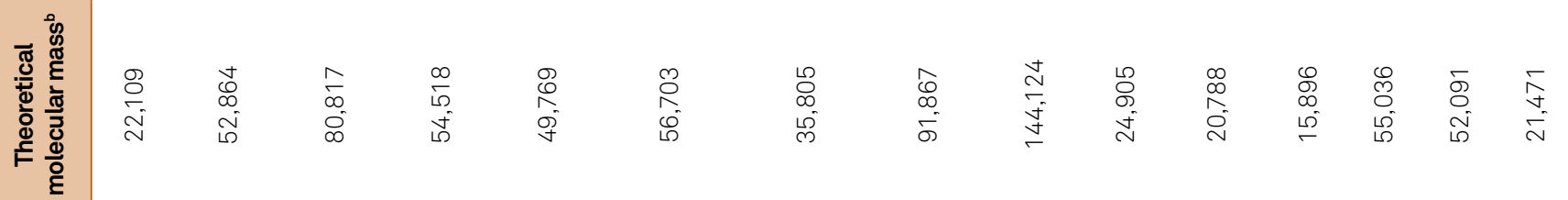

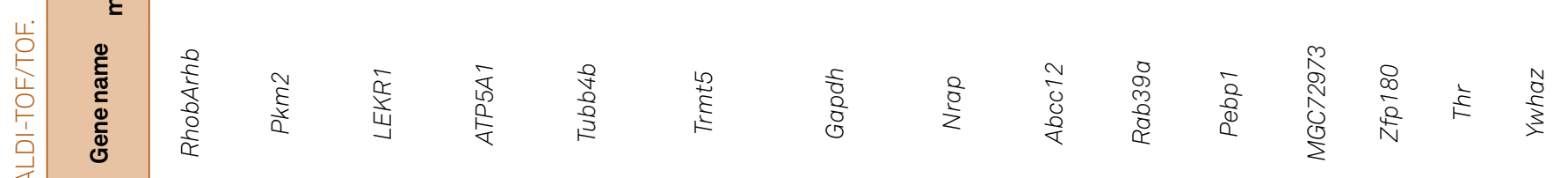

$$
\begin{aligned}
& \text { I } \\
& \text { 售| }
\end{aligned}
$$

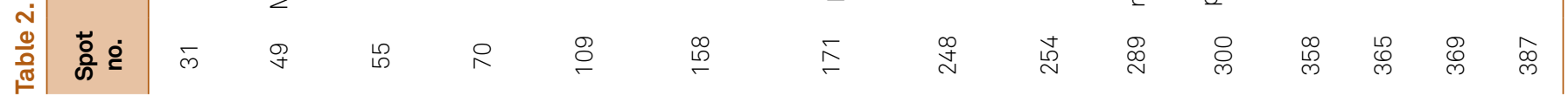



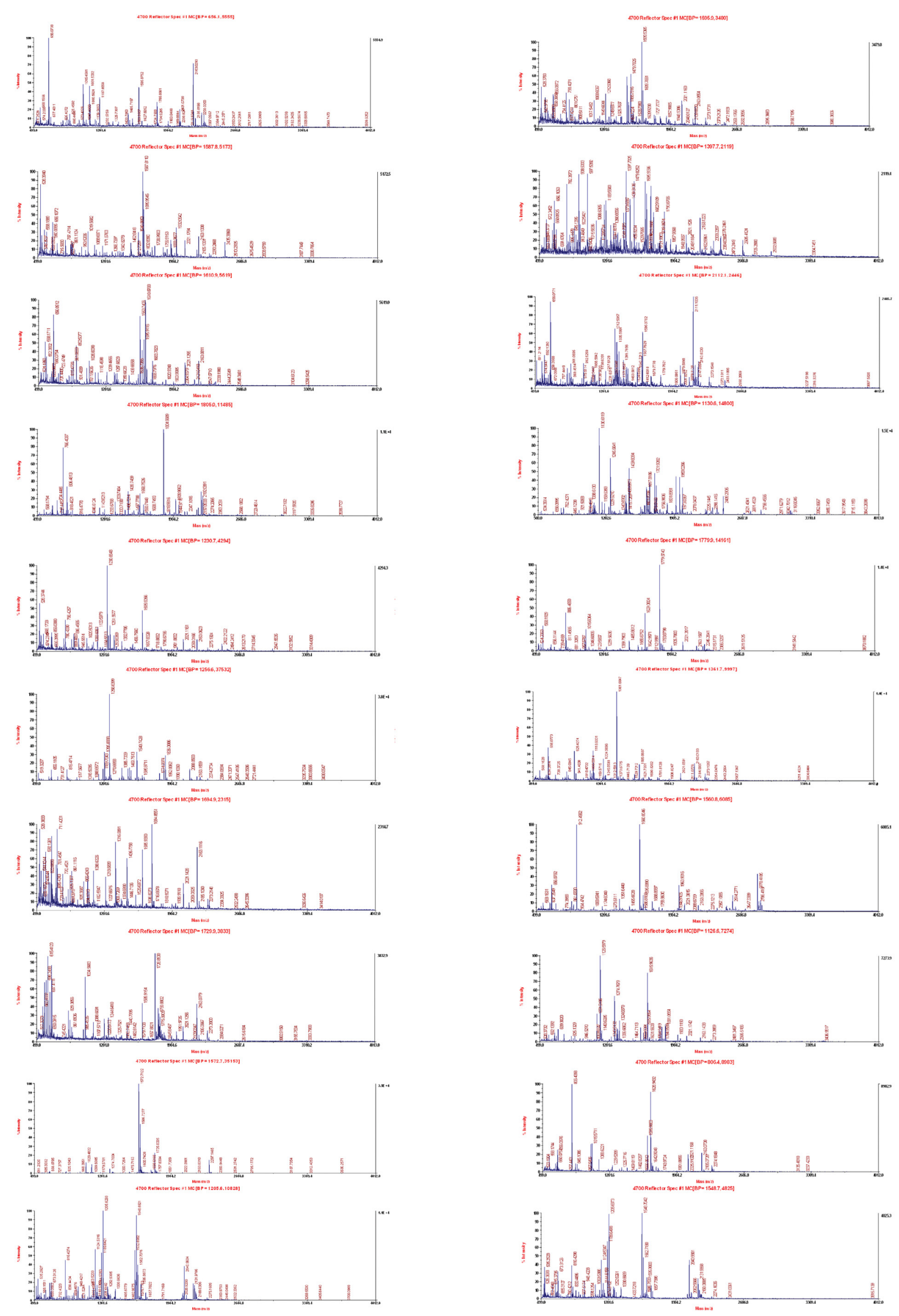

Figure 2. MALDI-TOF/TOF maps for the 20 identified proteins.

346 Arg Neuropsiquiatr 2015;73(4):342-349 
TBI. In clinical studies, serum NSE levels have been frequently studied. Berger et al. found that NSE was markedly increased in the CSF after severe $\mathrm{TBI}^{10}$. NSE levels were significantly elevated in non-survivors as compared with survivors in adults ${ }^{11}$. Early elevation ( $\leq 3$ days) of NSE secondary to severe TBI predicts deterioration to brain death. TopolovecVranic found that NSE was abnormally elevated in $65 \%$ of patients with TBI and predicted a poor outcome at 6 weeks post-injury ${ }^{12}$. NSE is also a candidate serum marker of impending cerebral hypoxia, which is elevated before the onset of clinical manifestations ${ }^{13}$. After multiple trauma, elevated NSE levels have been observed, but systemic NSE increased by similar degrees with and without TBI, limiting its ability to discriminate brain injury magnitude. Reports on correlations of serum NSE levels alone with clinical and neurological measures of brain injury magnitude and outcome have been controversial. NSE is not used widely clinically, perhaps because of the above and the lack of a large-scale, multi-center, randomized controlled study.

GFAP (spot no. 307) is a filament protein found in the astroglial cytoskeleton, is not found outside the CNS. GFAP could predictably discriminate between severe disability and vegetative state versus good and moderate outcomes as evaluated by the Glasgow Outcome Scale (GOS). A study of severe TBI patients confirmed its ability to predict mortality, and it was found to discriminate outcome categories of the GOS and Marshall CT classification. It also could discriminate between patients that had intracranial pressure (ICP) greater or less than $25 \mathrm{~mm} \mathrm{Hg}$, patients that had cerebral perfusion pressure greater or less than $60 \mathrm{~mm} \mathrm{Hg}$, and patients with mean arterial pressure greater or less than $60 \mathrm{~mm}$ Hg. GFAP shows good diagnostic potential to predict outcome after injury, and may also be valuable for diagnosing injury magnitude ${ }^{14}$.

S100B (spot no. 387) is the most well studied proteins for TBI and is considered a promising, non-proprietary brain injury biomarker. S100B is most abundant in glial cells of the CNS and peripheral nervous system (Schwann cells). But this marker is that it is not exclusive to the brain, it can be found in other cells such as adipocytes and chondrocytes. A number of studies have demonstrated S100B's relationship to injury magnitude and outcome in $\mathrm{TBI}^{5,14}$. However, some studies reported a poor value of S100B as a predictor of outcome after brain injury, particularly mild and pediatric TBI. A poor correlation was found between serum and brain S100B values, suggesting that the serum levels may depend primarily on the integrity of the blood-brain-barrier and do not reflect the S100B levels in the brain ${ }^{6,15}$. Despite apparent controversy, S100B still has potential as a brain injury biomarker, and its preclinical and clinical utility should be further explored.

$\alpha$ II-spectrin (spot no. 97) is a major structural component of the neuron axonal cytoskeleton and a major proteolytic substrate for cysteine proteases involved in necrotic and apoptotic cell death. Many authors have examined $\alpha$ II-spectrin after TBI in rats or humans. $\alpha$ II-spectrin levels in the CSF were shown to increase after TBI in a rat mod$\mathrm{el}^{16}$. In patients, Brophy found that $\alpha$ II-spectrin breakdown products (SBDPs) were significantly elevated in patients with worse Glasgow Coma Scale (GCS) scores 24 h after injury compared to those whose GCS scores improved ${ }^{17}$. The mean CSF levels of SBDPs were significantly higher in TBI patients than in controls and in patients who died than in those who survived, and the SBDP concentration was significantly greater in TBI patients than in controls and was correlated with the GCS score ${ }^{18}$. Therefore, $\alpha$ II-spectrin is an established biomarker of TBI.

MAP2 (spot no. 388) is important for microtubule stability and neural plasticity and appears to be among the most vulnerable of the cytoskeletal proteins following neuronal injury. Huh et al. found that MAP2 is an early, sensitive marker of neuronal damage following TBI. Early after TBI (2 hours) MAP2 expression decreased than that of control group. But in this study, we found that MAP2 was increased in TBI group. We speculate that the time of specimen harvesting led to this difference. In addition, MAP2 is an early blood marker in ischemic brain injury ${ }^{19}$. Therefore, MAP2 can be used as a marker for detecting neurotoxic insults, including ischemia and TBI.

There is a growing awareness that RhoB (spot no. 31) is also important signaling molecules in the CNS. RhoB is a member of the Rho GTPase family that is dramatically induced by brain ischemia or trauma. It seems likely that the increase in RhoB level plays a major role in determining the fate of the neurons, but there is little evidence as to whether the RhoB induction is beneficial or detrimental to neuronal survival. The increased RhoB expression promotes neurite outgrowth; but this increase is likely to make a substantial contribution to the neurodegenerative process, and also promotes caspase 3 activation and DNA fragmentation, key contributors to cell apoptosis ${ }^{20}$. RhoB mediates apoptosis in neoplastically transformed cells after DNA damage. Of the 20 proteins, GAPDH (spot no. 171) also participates in nuclear events, including transcription, RNA transport, DNA replication, and cell apoptosis ${ }^{21}$. Therefore, RhoB and GAPDH may play roles in neuro-cell apoptosis after TBI.

M2-PK (spot no. 49) is a phosphotyrosine-binding protein that has been studied in tumors, but not identified in TBI. M2-PK expression is critical for rapid growth in cancer cells ${ }^{22}$. It has been used in the diagnosis and surveillance of a variety of malignant diseases. With respect to injury, Oehler found that M2-PK expression and activity were increased in polytrauma patients compared to controls ${ }^{23}$. M2-PK is the product of the PKM2 gene. PKM2 gene transcription is activated by hypoxia-inducible factor 1 (HIF-1), i.e., when hypoxia occurs, such as after TBI, the PKM2 gene produces M2-PK. Pyruvate kinase (PK) orthologs in many organisms are inhibited by oxidants. Anastasiou found that the inhibition of M2-PK by reactive oxygen species contributes to cellular 
antioxidant responses ${ }^{24}$. Given the presence of hypoxia after TBI, M2-PK is a potential biomarker of TBI.

Another protein that has not previously been found after TBI is ATP-binding cassette protein C12 (spot no. 254). The gene for ATP-binding cassette protein $\mathrm{C} 12$ is $A b c c 12$ in rats and $A B C C 12$ in humans. The product of $A B C C 12$ is MRP9, which is expressed in breast tissue, brain, bone, and ovary ${ }^{25}$. SUR1, the product of $A b c c 8$, has been found in the CNS after TBI and has an effect on progressive hemorrhagic necrosis $(\mathrm{PHN})^{26}$. Abcc8 and Abcc12 are members of the Abcc superfamily and their products, SUR1 and MRP9, respectively, have been found in brain. Therefore, similar to SUR1, MRP9 might be an indicator of TBI.

The 14-3-3 protein (spot no. 387) family plays an important role in tumorigenesis and development. In addition, 14-3-3 protein is a biomarker of neurodegenerative diseas$\mathrm{es}^{27}$. In the motoneurons of rats, Namikawa reported that enhanced expression of the molecules involved in Ras-Erk signaling, such as 14-3-3 protein, is required for peripheral nerve regeneration $^{28}$. Apoptosis is important in cell death after TBI and is associated with B-cell lymphoma 2 (Bcl-2). 14-3-3 protein can bind Bcl-2-antagonist cell death (BAD) and then trigger cell apoptosis ${ }^{29}$. Consequently, 14-3-3 protein is a potential marker of apoptosis after TBI.
The remaining proteins, including leucine-, glutamate-, and lysine-rich protein 1, H(+)-transporting ATP synthase, nebulin-related anchoring protein, and zinc finger protein 180, have not been studied sufficiently and their functions after TBI have not been established. We can find no conclusive published relationships between these proteins and TBI. Therefore, more studies should target these proteins.

This study has several limitations. First, the study examined one time point after TBI (48 h), and the animal model was for moderate TBI. We did not determine protein expression at other times after TBI, nor did we determine protein expression in mild or severe TBI models. Second, the 20 proteins identified in the proteomic analysis have not been confirmed using Western blotting, immunohistochemistry, or reverse transcription polymerase chain reaction (RT-PCR) in animals or patients. Future work should focus on these limitations and identify protein expression at different time points in mild, moderate, and severe TBI, in animal models or in patients at one or more centers.

In general, this study validated several established biomarkers of TBI and identified other potential biomarkers that can be evaluated in the future.

\section{References}

1. Chiu WT, Huang SJ, Tsai SH, Lin JW, Tsai MD, Lin TJ et al. The impact of time, legislation, and geography on the epidemiology of traumatic brain injury. J Clin Neurosci. 2007;14(10):930-5. http://dx.doi.org/10.1016/j.jocn.2006.08.004

2. Centers for Disease Control and Prevention. TBI outcomes and consequences. [Cited 2005 July]. Available from: http://www.cdc.gov/ node.do/id/0900f3ec8000dbdc/aspectld/A0400027

3. Hergenroeder GW, Redell JB, Moore AN, Dash PK. Biomarkers in the clinical diagnosis and management of traumatic brain injury. Mol Diagn Ther 2008;12(6):345-58. http://dx.doi.org/10.2165/1250444-200812060-00002

4. Bazarian JJ, Zemlan FP, Mookerjee S, Stigbrand T. Serum S-100B and cleaved-tau are poor predictors of long-term outcome after mild traumatic brain injury. Brain Inj 2006;20(7):759-65.

5. Berger RP, Beers SR, Richichi R, Wiesman D, Adelson PD. Serum biomarker concentrations and outcome after pediatric traumatic brain injury.J Neurotraum. 2007;24(12):1793-801. http://dx.doi.org/10.1089/neu.2007.0316

6. Sun W, Xing B, Sun Y, Du X, Lu M, Hao C et al. Proteome analysis of hepatocellular carcinoma by two-dimensional difference gel electrophoresis: novel protein markers in hepatocellular carcinoma tissues. Mol Cell Proteomics. 2007;6(10):1798-808.

7. Ottens AK, Kobeissy FH, Fuller BF, Liu MC, Oli MW, Hayes RL et al. Novel neuroproteomic approaches to studying traumatic brain injury. Prog Brain Res. 2007;161:401-18. http://dx.doi.org/10.1016/S0079-6123(06)61029-7

8. Finnie JW. Animal models of traumatic brain injury: a review. Aust Vet J. 2001;79(9):628-33. http://dx.doi.org/10.1111/j.1751-0813.2001.tb10785.x

9. Sullivan PG, Keller JN, Bussen WL, Scheff SW. Cytochrome c release and caspase activation after traumatic brain injury. Brain Res. 2002;949(1-2):88-96. http://dx.doi.org/10.1016/S0006-8993(02)02968-2
10. Berger RP, Pierce MC, Wisniewski SR, Adelson PD, Clark RS, Ruppel RA et al. Neuron-specific enolase, and S100B in cerebrospinal fluid after severe traumatic brain injury in infants and children. Pediatrics. 2002;109(2):E31.

11. Böhmer AE, Oses JP, Schmidt AP, Perón CS, Krebs CL, Oppitz PP et al. Fibrillary acidic protein levels as outcome predictors in patients with severe traumatic brain injury. Neurosurg. 2011;68(6):1624-31. http://dx.doi.org/10.1227/NEU.0b013e318214a81f

12. Topolovec-Vranic J, Pollmann-Mudryj MA, Ouchterlony D, Klein D, Spence J, Romaschin A et al. The value of serum biomarkers in prediction models of outcome after mild traumatic brain injury. J Trauma. 2011;71(5 Suppl 1):S478-86. http://dx.doi.org/10.1097/TA.0b013e318232fa70

13. Stein DM, Lindell AL, Murdock KR, Kufera JA, Menaker J, Bochicchio GV et al. Use of serum biomarkers to predict cerebral hypoxia after severe traumatic brain injury. J Neurotrauma. 2012;29(6):1140-9. http://dx.doi.org/10.1089/neu.2011.2149

14. Pelinka LE, Kroepfl A, Leixnering M, Buchinger W, Raabe, A, Redl H. GFAP versus $\mathrm{S} 100 \mathrm{~B}$ in serum after traumatic brain injury: relationship to brain damage and outcome.J Neurotrauma. 2004;21(11):1553-61. http://dx.doi.org/10.1159/000103304

15. Piazza O, Storti MP, Cotena S, Stoppa F, Perrotta D, Esposito G et al. $\mathrm{S} 100 \mathrm{~B}$ is not a reliable prognostic index in paediatric TBI. Pediatr. Neurosurg. 2007;43(4):258-64.

16. Aikmana J, O'Steen B, Silver X, Torres R, Boslaugh S, Blackband $S$ et al. Alpha-Il-spectrin after controlled cortical impact in the immature rat brain. Dev Neurosci. 2006;28(4-5):457-65. http://dx.doi.org/10.1159/000094171

17. Brophy GM, Pineda JA, Papa L, Lewis SB, Valadka AB, Hannay HJ et al. alphall-Spectrin breakdown product cerebrospinal fluid exposure metrics suggest differences in cellular injury mechanisms after severe traumatic brain injury. J Neurotraum. 2009;26(4):471-9. http://dx.doi.org/10.1089/neu.2008.0657 
18. Berger RP, Hayes R, Richichi R, Beers SR, Wang KK. Serum concentrations of ubiquitin C-terminal hydrolase- $L 1$ and alll-spectrin breakdown product $145 \mathrm{kDa}$ correlate with outcome after pediatric TBI. J Neurotrauma. 2012;29(1):162-7. http://dx.doi.org/10.1089/neu.2011.1989

19. Park D, Joo SS, Lee HJ, Choi KC, Kim SU, Kim YB. Microtubule-associated protein 2, an early blood marker of ischemic brain injury. J Neurosci Res. 2012;90(2):461-7. http://dx.doi.org/10.1002/jnr.22769

20. Barberan S, McNair K, Iqbal K, Smith NC, Prendergast GC, Stone TW et al. Altered apoptotic responses in neurons lacking RhoB GTPase. Eur J Neurosci. 2011;34(11):1737-46. http://dx.doi.org/10.1111/j.1460-9568.2011.07891.x

21. Tisdale EJ. Glyceraldehyde-3-phosphate dehydrogenase is phosphorylated by protein kinase Ciota /lambda and plays a role in microtubule dynamics in the early secretory pathway. J Biol Chem. 2002;277(5):3334-41. http://dx.doi.org/10.1074/jbc.M109744200

22. Christofk HR, Heiden MG, Wu N, Asara JM, Cantley LC. Pyruvate kinase $\mathrm{M} 2$ is a phosphotyrosine-binding protein. Nature. 2008;452(7184):181-6. http://dx.doi.org/10.1038/nature06667

23. Luo W, Hu H, Chang R, Zhong J, Knabel M, O'Meally R et al. Pyruvate kinase M2 is a PHD3-stimulated coactivator for hypoxia-inducible factor 1. Cell. 2011;145(5):732-44. http://dx.doi.org/10.1016/j.cell.2011.03.054
24. Anastasiou D, Poulogiannis G, Asara JM, Boxer MB, Jiang JK, Shen $\mathrm{M}$ et al. Inhibition of pyruvate kinase $\mathrm{M} 2$ by reactive oxygen species contributes to cellular antioxidant responses. Science. 2011;334(6060):1278-83. http://dx.doi.org/10.1126/science.1211485

25. Bera TK, lavarone C, Kumar V, Lee S, Lee B, Pastan I. MRP9, an unusual truncated member of the ABC transporter superfamily, is highly expressed in breast cancer. Proc Natl Acad Sci USA. 2002;99(10):6997-7002. http://dx.doi.org/10.1073/pnas.102187299

26. Simard JM, Tsymbalyuk O, Ivanov A, Ivanova S, Bhatta S, Geng Z et al. Endothelial sulfonylurea receptor 1 - regulated NC Ca-ATP channels mediate progressive hemorrhagic necrosis following spinal cord injury. J Clin Invest. 2007;117(8):2105-13. http://dx.doi.org/10.1172/JCl32041

27. Bersano A, Fiorini M, Allaria S, Zanusso G, Fasoli E, Gelati M et al. Detection of CSF 14-3-3 protein in Guillain-Barré syndrome. Neurology. 2006;67(12):2211-6. http://dx.doi.org/10.1212/01.wnl.0000249150.98891.d1

28. Namikawa K, Su Q, Kiryu-Seo S, Kiyama H. Enhanced expression of 14-3-3 family members in injured motoneurons. Brain Res Mol Brain Res. 1998;55(2):315-20. http://dx.doi.org/10.1016/S0169-328X(98)00012-6

29. Datta SR, Katsov A, Hu L, Petros A, Fesik SW, Yaffe MB et al. 14-3-3 proteins and survival kinases cooperate to inactivate BAD by BH3 domain phosphorylation. Mol Cell. 2000;6(1):41-51. http://dx.doi.org/10.1016/S1097-2765(00)00006-X 